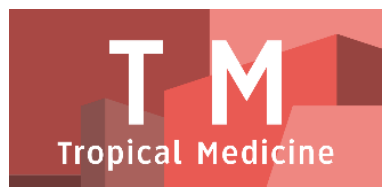

PAPER - OPEN ACCESS

\title{
Kondisi Rongga Mulut terhadap Kualitas Hidup Ibu Hamil di Puskesmas di Medan
}

\author{
Author : Rika Mayasari Alamsyah \\ DOI $\quad: 10.32734 /$ tm.v1i1.64 \\ Paper Page : $330-335$
}

Volume 1 Issue 1 - 2018 TALENTA Conference Series: Tropical Medicine (TM)

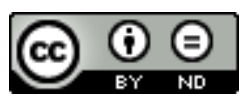

This work is licensed under a Creative Commons Attribution-NoDerivatives 4.0 International License.

Published under licence by TALENTA Publisher, Universitas Sumatera Utara
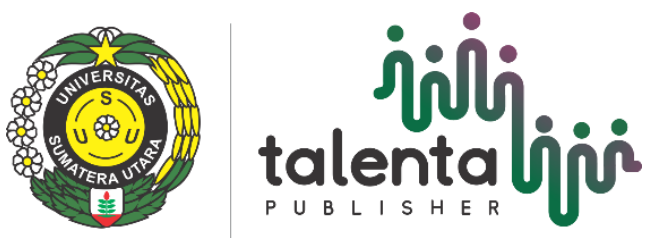


\title{
Kondisi Rongga Mulut terhadap Kualitas Hidup Ibu Hamil di Puskesmas di Medan
}

\author{
Rika Mayasari Alamsyah ${ }^{\mathrm{a}}$ \\ ${ }^{a}$ Fakultas Kedokteran Gigi, Universitas Sumatera Utara 20155, Indonesia \\ rika_165@yahoo.com
}

\begin{abstract}
Abstrak
Kehamilan merupakan suatu proses fisiologis yang menimbulkan perubahan pada tubuh wanita baik fisik maupun psikis. Selama kehamilan terjadi perubahan pada rongga mulut terkait dengan perubahan hormonal, perubahan pola makan, perubahan perilaku dan berbagai keluhan seperti ngidam, mual dan muntah. Ibu hamil menjadi sangat rentan terhadap penyakit gingival danpenyakit periodontal akibat dari kebiasaan mengabaikan kebersihan gigi dan mulut. Tingginya tingkat terjadinya penyakit mulut juga dapat berdampak pada kualitas hidup yang berhubungan dengan kesehatan rongga mulut pada ibu hamil.

Tujuan penelitian ini untuk mengetahui persentase perdarahan gingiva dan kualitas hidup ibu hamil di beberapa Puskesmas di Medan. Jenis penelitian ini adalah penelitian survei deskriptif. Populasi penelitian ini adalah ibu hamil yang datang ke Puskesmas, dengan sampel sebanyak 100 orang. Pengambilan data perdarahan gingiva dan kualitas hidup menggunakan instrument Oral Health Impact Profile (OHIP-14) dilakukan dengan wawancara dan dicatat dalam kuesioner. Hasil penelitian menunjukkan $74 \%$ sampel mengalami perdarahan gingiva. Pada pengukuran kualitas hidup diperoleh $12 \%$ pada dimensi keterbatasan fungsi mengalami kesulitan pengecapan, $16 \%$ pada dimensi rasa sakit fisik mengalami tidak nyaman mengunyah makanan, $2 \%$ pada dimensi ketidaknyamanan psikis mengalami rasa cemas, $16 \%$ pada dimensi ketidakmampuan fisik mengalami terhenti saat makan, $20 \%$ pada dimensi ketidakmampuan psikis mengalami rasa malu, $6 \%$ pada dimensi ketidakmampuan social mengalami mudah tersinggung dan hanya $1 \%$ pada dimensi hambatan mengalami tidak mampu beraktivitas. Dapat disimpulkan kondisi rongga mulut dapat mempengaruhi kualitas hidup ibu hamil selama masa kehamilan, terutama pada dimensi ketidakmampuan psikis, rasa sakit fisik dan ketidakmampuan fisik.
\end{abstract}

Kata Kunci: rongga mulut, kualitas hidup, ibu hamil;

\section{Pendahuluan}

Kehamilan merupakan suatu proses fisiologis yang menimbulkan perubahan pada tubuh wanita baik fisik maupun psikis.Ibu hamil harus menyadari pentingnya menjaga kesehatan mulut selama kehamilan untuk dirinya sendiri serta janin yang dikandung sehingga dapat menghindari terjadinya penyakit mulut yang dapat mempengaruhi kehamilan (Applonia, Priyono B, Widyanti N. 2014).

Selama kehamilan terjadi perubahan pada rongga mulut terkait dengan perubahan hormonal, perubahan pola makan, perubahan perilaku dan berbagai keluhan seperti ngidam, mual dan muntah. Ibu hamil menjadi sangat rentan terhadap penyakit gingival dan penyakit periodontal akibat dari kebiasaan mengabaikan kebersihan gigi dan mulut (Anggraini R, Andreas P.2015).Sourabha K.G., et al (2014) menyatakan tingginya tingkat terjadinya penyakit mulut juga dapat berdampak pada kualitas hidup yang berhubungan dengan kesehatan rongga mulut pada ibu hamil. 


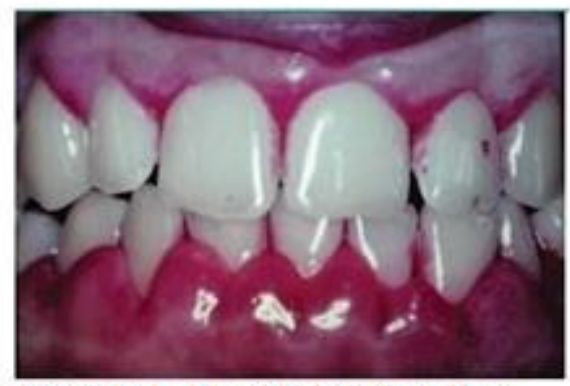

Gambar 1. Gingivitis kehamilan

Menurut WHO, kualitas hidup didefinisikan sebagai persepsi individu dalam hidup, ditinjau dari konteks budaya dan sistem nilai dimana mereka tinggal, berhubungan dengan standar hidup, harapan, kesenangan dan perhatian mereka.Slade (1997) menyerderhanakan OHIP yang terdiri dari 49 pertanyaan (OHIP-49) menjadi OHIP dengan 14 butir pertanyaan (OHIP-14). OHIP-14 ini berhubungan dengan tujuh dimensi yaitu keterbatasan fungsi, rasa sakit, ketidaknyamanan psikis, ketidakmampuan fisik, ketidakmampuan psikis, ketidakmampuan sosial dan hambatan. OHIP-14 dapat juga digunakan untuk mengukur kualitas hidup pada ibu hamil.

Hasil penelitian Archaya dan Bhat (2009) di India menunjukkan persentase wanita hamil yang mengalami rasa sakit fisik yaitu 45,2\% dan mengalami ketidakmampuan fisik yaitu 22\%. Sedangkan penelitian De Oliveira dan Nadanovsky (2006) di Brazil menyebutkan bahwa 14,7\% dari ibu hamil mengalami kesulitan dalam melakukan aktivitas sehari-hari.Hasil penelitian Saei EY dkk. (2011), di Malaysia melaporkan adanya keluhan bau mulut sebesar 13\% dan perasaan malu sebesar 9\% karena memiliki masalah gigi dan mulut.Penelitian Class dkk., di Wellington, New Zealand melaporkan lebih dari $60 \%$ adanya gusi berdarah pada ibu hamil.

Penelitian ini bertujuan untuk mengetahui persentase perdarahan gingiva dan kualitas hidup ibu hamil di beberapa Puskesmas di Medan.

\section{Bahan dan Metode}

Jenis penelitian ini adalah penelitian survei deskriptif. Penelitian ini dilakukan di beberapa Puskesmas di kota Medan yaitu : Puskesmas Padang Bulan, Puskesmas Darussalam dan Puskesmas Medan Deli. Populasi penelitian ini adalah ibu hamil yang datang ke Puskesmas. Penentuan jumlah sampel berdasarkan metodetotal sampling, sampel diambil dari seluruh pasien yang datang selama 3 hari di lokasi penelitian sebanyak 100 orang.

Pengambilan data perdarahan gingiva dan kualitas hidup menggunakan instrumen Oral Health Impact Profile (OHIP-14)dilakukan dengan wawancara dan dicatat dalam kuesioner. OHIP-14 terdiri dari 7 dimensi, yang setiap dimensi terdiri dari dua pertanyaan, dan menggunakan lima skala likert, yaitu $0=$ tidak pernah, $1=$ jarang, $2=$ kadang-kadang, $3=$ sering, dan $4=$ =sangat sering. Total skor yang tinggi menunjukkan kualitas hidup yang rendah begitu pula sebaliknya.

Pengolahan data dilakukan dengan menggunakan komputerisasi. Data dianalisis secara deskriptif dan hasilakanditampilkandalamtabe

\section{Hasil}

. Hasil penelitian menunjukkan karakteristik responden pada tingkat pendidikan ibu hamil yang berkunjung ke Puskesmas Padang Bulan, Puskesmas Darussalam dan Puskesmas Medan Deli yaitu 58\% SMA, SMP 29\%, 
perguruan tinggi $10 \%$, SD $2 \%$ dan tidak sekolah 1\%. Responden terbanyak yaitu pada trimester ketiga $60 \%$, trimester kedua $34 \%$ dan trimester pertama $6 \%$ dengan status kehamilan terbesar pada primigravida sebesar $79 \%$ dan multigravida $21 \%$ (Tabel 1).

Tabel 1. Karakteristik responden ibu hamil berdasarkan tingkat pendidikan, usia kehamilan danstatus kehamilan

\begin{tabular}{|l|c|c|}
\hline \multicolumn{1}{|c|}{ Karakteristik Ibu Hamil } & $\mathrm{n}$ & $\%$ \\
\hline Tingkat Pendidikan & 1 & 1 \\
Tidak Sekolah & 2 & 2 \\
SD SMP SMA & 29 & 29 \\
PerguruanTinggi & 58 & 58 \\
& 100 & 100 \\
\hline Total & 100 & 6 \\
\hline Usia Kehamilan & & 34 \\
\hline Trimester 1 & 6 & 60 \\
\hline Trimester 2 & 34 & 100 \\
\hline Trimester 3 & 60 & \\
\hline Total & 100 & \\
\hline Status Kehamilan & & \\
Primigravida & 21 & \\
Multigravida & 79 & \\
\hline Total & 100 & \\
\hline
\end{tabular}

Hasil penelitian menunjukkan sebagian responden kadang-kadang mengalami gusi berdarah sebesar 58\%, tidak pernah $26 \%$ dan yang pernah mengalami $16 \%$ (Tabel 2).

Tabel 2.Persentase responden berdasarkan perdarahan gingiva

\begin{tabular}{|l|c|c|}
\hline \multicolumn{1}{|c|}{ Perdarahan Gingiva } & $\mathrm{n}$ & $\%$ \\
\hline Ya & 16 & 16 \\
Kadang-kadang & 58 & 58 \\
Tidak & 26 & 26 \\
\hline Total & 100 & 100 \\
\hline
\end{tabular}

Pada dimensi keterbatasan fungsi, akibat kondisi gigi dan mulut $44 \%$ responden tidak pernah mengalami kesulitan berbicara, kadang 29\%, jarang 17\%, sering dan sangat sering sebesar $10 \%$ dan $43 \%$ responden kadang merasa kesulitan pengucapan, jarang 26\%, tidak pernah $20 \%$ dan sering dan sangat sering sebesar $11 \%$. Pada dimensi sakit fisik, 37\% responden yang kadang merasa sakit hebat, tidak pernah $33 \%$, jarang $20 \%$, sering dan sangat sering $10 \%$ dan responden yang kadang merasa ketidaknyamanan saat makan sebesar 38\%, jarang $27 \%$, tidak pernah $19 \%$ dan sering dan sangat sering sebesar $16 \%$ karena kondisi gigi dan mulut.

Pada dimensi ketidaknyamanan psikis, akibat kondisi gigi dan mulut 35\%responden yang kadang mengalami cemas, tidak pernah $34 \%$, jarang $29 \%$, sering dan sangat sering sebesar $2 \%$ dan responden yang tidak pernah merasa tegang sebesar 53\%, jarang 25\%, dan kadang 22\%. Pada dimensi fisik, $46 \%$ responden yang kadang puas mengkonsumsi makanan tertentu,tidak pernah $20 \%$, sering dan sangat sering sebesar $12 \%$ dan responden yang merasa kadang terhenti saat makan sebesar 37\%, jarang 29\%, tidak pernah 18\%, sering dan sangat sering sebesar $16 \%$ karena kondisi gigi dan mulut.

Pada dimensi ketidakmampuan psikis, akibat kondisi gigi dan mulut $38 \%$ responden yang kadang

merasa sulit rileks, tidak pernah $28 \%$, jarang $22 \%$, sering dan sangat sering sebesar $12 \%$ dan responden yang kadang pernah merasa malu sebesar $37 \%$, tidak pernah 22\%, jarang $21 \%$, sering dan sangat sering $20 \%$ karena kondisi gigi dan mulut. Pada dimensi ketidakmampuan sosial, akibat kondisi gigi dan mulut $38 \%$ respondenyang 
tidak pernah merasa tersinggung, kadang 35\%, jarang $21 \%$ dan sering $6 \%$. Responden yang jarang merasa kesulitan melakukan pekerjaan sehari-hari sebesar 42\%, kadang 29\%, tidak pernah $27 \%$ dan sering $3 \%$.

Pada dimensi hambatan, akibat kondisi gigi dan mulut 56\% responden yang tidak pernah merasa hidup kurang memuaskan, jarang $22 \%$ dan kadang $22 \%$ dan responden yang tidak pernah tidak dapat beraktivitas sebesar 39\%, kadang 30\%, jarang 29\%, sering dan sangat sering $2 \%$ (Tabel 4 )

Tabel 4.Frekuensi distribusi kualitas hidup ibu hamil

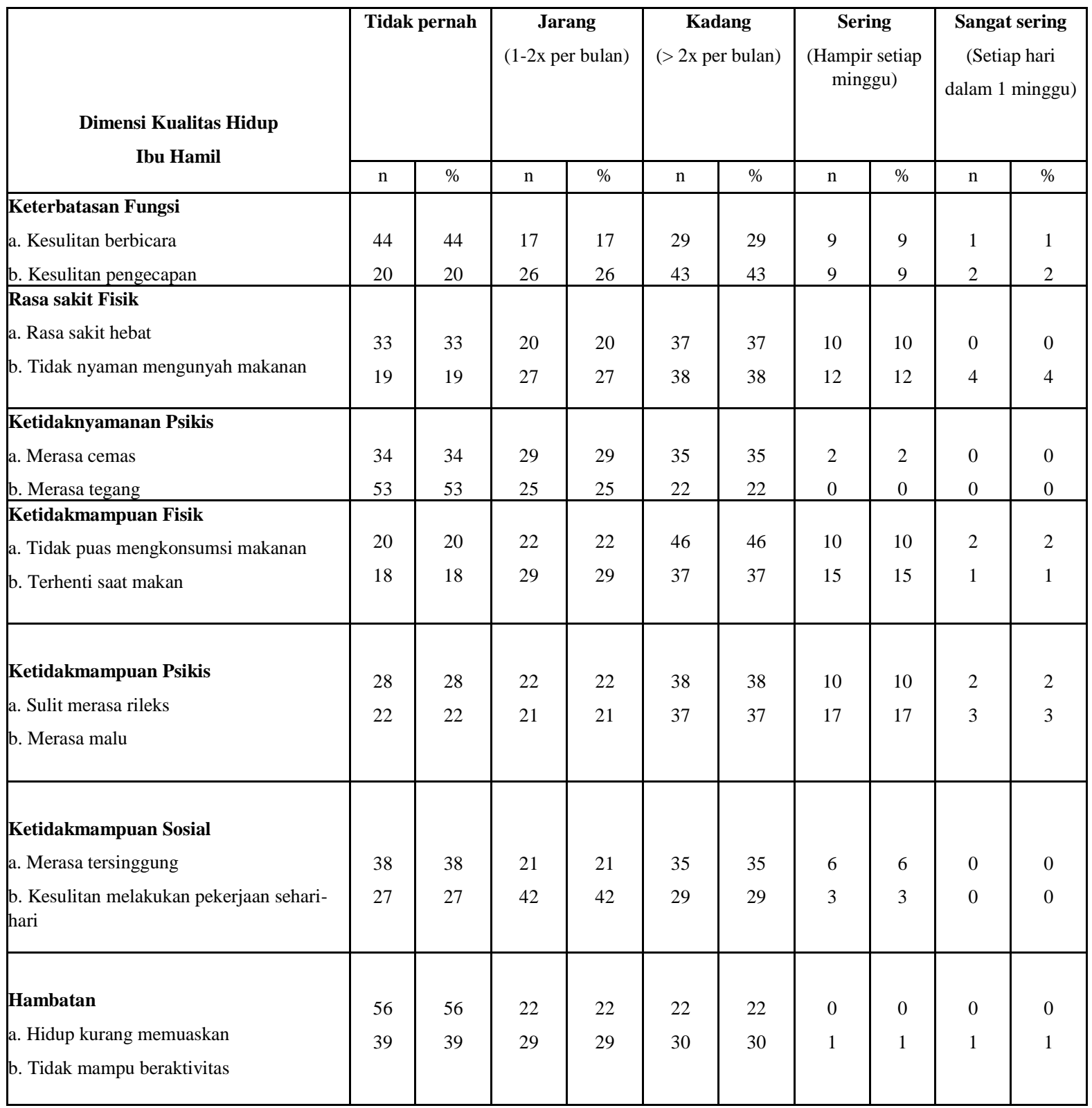

\section{Pembahasan}

Hasil penelitian menunjukkan $74 \%$ ibu hamil mengalami perdarahan pada gingiva. Hasil ini lebih tinggi dari penelitian Class dkk., menunjukkan sebanyak $60 \%$ dilaporkan adanya pendarahan pada gingiva. Hal ini 
memperlihatkan kondisi rongga mulut sampel lebih buruk, yang mungkin dikarenakan tingkat pendidikan yang lebih rendah sehingga sampel kurang memperhatihan kondisi rongga mulutnya ditambah dengan respon inflamasi terhadap plak gigi meningkat selama masa kehamilan sehingga menyebabkan pembengkakan gingiva yang cenderung berdarah saat menyikat gigi.

Pada dimensi keterbatasan fungsi, 10\% ibu hamil mengalami kesulitan berbicara dan $11 \%$ merasa kesulitan pengecapan karena kondisi gigi dan mulut. Hasil ini lebih tinggi dari penelitian Acharya dkk,.yang menyatakan ibu hamil yang mengalami kesulitan berbicara sebesar $0,8 \%$ dan merasa kesulitan pengecapan sebesar 6,6\%. Hal ini mungkin disebabkan karena tingkat pendidikan sampel, yang 90\% hanya berpendidikan SMA ke bawah sehingga kurang memperhatikan kesehatan rongga mulutnya oleh karena itu, adanya efek kondisi rongga mulut saat kehamilan seperti gingivitis, epulis, mobiliti gigi, adanya karies, dan erosi gigi mengakibatkan sulit berbicara dan sulit mengecap makanan.

Pada dimensi rasa sakit fisik, $10 \%$ ibu hamil yang merasa sakit hebat dan $16 \%$ merasa tidak nyaman mengunyah makanan karena kondisi gigi dan mulut.Hasil ini lebih rendah dari penelitian Acharya dkk,.untuk ibu hamil yang merasa sakit hebat sebesar 23,5\%, hampir sama untuk yang merasa ketidaknyamanan saat makan sebesar 14,6\%. Hal ini mungkin dikarenakanambang rasa sakit yang tinggi pada sampel, karena sudah terbiasa merasakan sakit gigi sebelum hamil.

Pada dimensi ketidaknyamanan psikis, $2 \%$ ibu hamil yang merasa cemas karena kondisi gigi dan mulut. Hasil ini hampir sama dengan penelitian Acharyadkk., yang mengungkapkan ibu hamil yang mengalami merasa cemas sebesar $2,7 \%$. Hal ini mungkin dikarenakan ibu hamil fokus terhadap kehamilannya sehingga tidak terlalu cemas dengan kondisi rongga mulutnya.

Pada dimensi ketidakmampuan fisik, 12\% ibu hamil yang tidak puas mengkonsumsi makanan dan $16 \%$ terhenti saat makan karena kondisi gigi dan mulut. Hasil ini lebih tinggi dari penelitian Acharya dkk., yang mengungkapkan ibu hamil yang tidak puas mengkonsumsi makanan tertentu sebesar 7,4\% dan terhenti saat makan sebesar 7,7\%. Hal ini mungkin disebabkan adanya perbedaan sosial ekonomi pada sampel, ibu-ibu yang berobat di puskesmas biasanya dari golongan menengah ke bawah yang jarang pergi ke dokter gigi untuk merawat giginya sehingga banyak terdapat karies di rongga mulut yang mengganggu pada saat mengonsumsi makanan.

Pada dimensi ketidakmampuan psikis, 14\% ibu hamil yang sulit merasa rileks danmerasa malu sebesar 20\%karena kondisi gigi dan mulut. Hasil ini lebih tinggi dari penelitian Acharya dkk., yang mengungkapkan ibu hamil yang merasa sulit rileks sebesar 3,1\%dan merasa malu sebesar 3,1\%. Hal ini juga mungkin dikarenakan perbedaaan sosial ekonomi dari sampel, dengan banyaknya karies tentunya penampilan estetis terganggu sehingga menyebabkan gangguan psikis pada ibu hamil.

Pada dimensi ketidakmampuan sosial, 6\% ibu hamil yang merasa tersinggung dan 3\% kesulitan melakukan pekerjaan sehari-hari. Hasil ini lebih tinggi dari penelitian Acharya dkk., yang mengungkapkan ibu hamil yang merasa tersinggung sebesar 0,4\%dan merasakan kesulitan pekerjaan sehari-hari sebesar $0,4 \%$. Hal ini juga mungkin dikarenakan perbedaaan sosial ekonomi dari sampel, yang mengakibatkan ibu-ibu hamil jarang berobat ke dokter gigi sehingga keluhan di rongga mulut tidak teratasi dengan baik mengakibatkan mereka mengalami gangguan pada dimensi ini.

Pada dimensi hambatan, tidak ada ibu hamil yang merasa hidup kurang memuaskan dan $1 \%$ tidak mampu beraktivitas karena kondisi gigi dan mulut. Hasil ini tidak jauh berbeda dengan penelitian Acharyadkk., yang mengungkapkan ibu hamil yang merasa hidup kurang memuaskan sebesar 1,5\%dan tidak dapat beraktivitas sebesar $0,8 \%$. Hal inimemperlihatkan bahwa tidak banyak ibu hamil yang mengalami hambatan karena kondisi rongga mulutnya selama kehamilan.

\section{Kesimpulan}

Kondisi rongga mulut dapat mempengaruhi kualitas hidup ibu hamil selama masa kehamilan, terutama padadimensiketidakmampuanpsikis, rasa sakit fisik dan ketidakmampuan fisik. 


\section{Daftar Pustaka}

[1] Applonia, Priyono B, Widyanti N. Faktor - faktor yang mempengaruhi perilaku pemeliharaan kebersihan gigi dan mulut ibu hamil di Puskesmas Kabupaten Kupang. Maj Ked GI. Juni 2014; 21(1): 20-26.

[2] Anggraini R, Andreas P. Kesehatan gigi mulut dan pemanfaatan pelayanan kesehatan gigi mulut pada ibu hamil (Studi Pendahuluan di Wilayah Puskesmas Serpong, Tanggerang Selatan). Maj Ked GI. Desember 2015; 1(2): 193-200.

[3] Soulissa AG. Hubungan Kehamilan dan Penyakit Periodontal. Jurnal PDGI. September - Desember 2014; 63(3): 71-77.

[4] Sourabha K.G., Puranik MP, Sowmya K.R. et. Al. Association of self perceived oral health on oral health related quality of life among pregnant and non pregnant women in Bangalore city. Int J Health Sci Res. 2014; 4(4): 120-127.

[5] Brennan DS, Spencer AJ. Dimensions of oral health related quality of life measured by EQ-5D+ and OHIP-14. Health and Quality of Life Outcomes, 2004;2:35.

[6] Acharya S, Bhatpv, Acharya S. Factors affecting oral health-related quality of life among pregnant women. Int J Dent Hygiene 7, 2009; $102-107$.

[7] De Oliveira BH, Nadanovsky P. The impact of oral pain on quality of life during pregnancy in low- income Brazilian women. J Orofac Pain 2006; 20: 297-305.

[8] Sari EY, Saddki N, Yusoff A. Oral health - related quality of life among pregnant women at Hospital UniversitiSains Malaysia, In The Annual International Conference Syiah Kuala University 2011.

[9] Soulissa AG. HubunganKehamilandanPenyakitPeriodontal.Jurnal PDGI 2014; 63; 72.

[10] Ovadia R, Zirdok R, Diaz-Romero RM. Relationship between pregnancy and periodontal disease. FactaUniversitatis series Medicine and Biology 2007;14(1);10-14.

[11] Silk H, Douglass AB, Douglass JM, Silk L. Oral health during pregnancy. Am Family Phyician 2008: 1139-44. 